\title{
Casein phosphopeptides drastically increase the secretion of extracellular proteins in Aspergillus awamori. Proteomics studies reveal changes in the secretory pathway
}

\author{
Katarina Kosalková1, Carlos García-Estrada', Carlos Barreiro', Martha G Flórez², Mohammad S Jami²,
} Miguel A Paniagua ${ }^{1}$ and Juan F Martín ${ }^{1,2^{*}}$

\begin{abstract}
Background: The secretion of heterologous animal proteins in filamentous fungi is usually limited by bottlenecks in the vesicle-mediated secretory pathway.

Results: Using the secretion of bovine chymosin in Aspergillus awamori as a model, we found a drastic increase (40 to 80-fold) in cells grown with casein or casein phosphopeptides (CPPs). CPPs are rich in phosphoserine, but phosphoserine itself did not increase the secretion of chymosin. The stimulatory effect is reduced about $50 \%$ using partially dephosphorylated casein and is not exerted by casamino acids. The phosphopeptides effect was not exerted at transcriptional level, but instead, it was clearly observed on the secretion of chymosin by immunodetection analysis. Proteomics studies revealed very interesting metabolic changes in response to phosphopeptides supplementation. The oxidative metabolism was reduced, since enzymes involved in fermentative processes were overrepresented. An oxygen-binding hemoglobin-like protein was overrepresented in the proteome following phosphopeptides addition. Most interestingly, the intracellular pre-protein enzymes, including pre-prochymosin, were depleted (most of them are underrepresented in the intracellular proteome after the addition of (PPS), whereas the extracellular mature form of several of these secretable proteins and cell-wall biosynthetic enzymes was greatly overrepresented in the secretome of phosphopeptides-supplemented cells. Another important 'moonlighting' protein (glyceraldehyde-3-phosphate dehydrogenase), which has been described to have vesicle fusogenic and cytoskeleton formation modulating activities, was clearly overrepresented in phosphopeptides-supplemented cells.
\end{abstract}

Conclusions: In summary, CPPs cause the reprogramming of cellular metabolism, which leads to massive secretion of extracellular proteins.

Keywords: secretory pathways, chymosin, filamentous fungi, casein phosphopeptides, vesicles, extracellular proteins

\section{Background}

Filamentous fungi are very attractive host organisms for the production of heterologous proteins, since they have several advantages for protein expression compared to bacterial hosts. These advantages include i) the ability to produce large amounts of extracellular proteins, ii) the

\footnotetext{
* Correspondence: jf.martin@unileon.es

'From INBIOTEC, Instituto de Biotecnología de León, Avda. Real n. 1, Parque Científico de León, 24006 León, Spain

Full list of author information is available at the end of the article
}

GRAS status in the food industry of several filamentous fungi such as Aspergillus niger, Aspergillus awamori, Aspergillus oryzae, Penicillium roqueforti among others $[1,2]$, iii) rapid growth compared to other eukaryotic cells, iv) the secretion of correctly folded functional proteins and v) post-translational modifications, such as glycosylation. However, the levels of secreted heterologous proteins are often limited by poorly understood bottlenecks in the secretory pathway [3,4]. In many cases, limiting steps in the heterologous protein secretion occur

\section{C) Biomed Central}


during protein movement through the secretory pathway [5-9]. Particularly, structural or regulatory proteins affecting the traffic through the secretory vesicles are unknown. Therefore, a good understanding of the protein-secretion pathway is needed for the improvement of heterologous proteins production in industrial processes. Proteomics is an excellent tool for this study.

The protein secretion pathway in filamentous fungi is similar to that present in yeasts and higher eukaryotes, but protein secretion is believed to occur mainly at hyphal tips $[10,11]$. The classical secretory pathway of proteins across membranes starts with the recognition and cleavage of a canonical $\mathrm{N}$-terminal signal peptide (the pre sequence). These proteins enter the endoplasmic reticulum (ER), where they are correctly folded and modified (glycosylation, phosphorylation, etc) $[9,12]$ and later reach the Golgi compartment, where proteins can undergo additional modifications, such as changes of the lateral chains of some amino acids, the addition or trimming down of sugars and other types of peptide processing. After this step, proteins are packed in secretory vesicles and directed to the plasma membrane for secretion, or targeted to the vacuole either to become resident proteins or to undergo proteolytic degradation $[6,13]$. Heterologous proteins might lack some of the features needed to be efficiently recognized as genuine secretory proteins and, therefore, their secretion is more difficult.

Filamentous fungi of industrial interest include $A$. niger [2] and the closely related species A. awamori, widely used for the expression of homologous (e.g. glucoamylase) and heterologous proteins, such as human lactoferrin [14], cytokines [15] and proteins for the food industry including bovine chymosin [16,17] or thaumatin [8].

Bovine chymosin, an aspartyl protease extracted from the abomasum of suckling calves is an excellent model protein to study possible bottlenecks in the secretion of heterologous proteins. It is synthesized in vivo as preprochymosin and secreted as prochymosin (with a molecular mass of $46 \mathrm{kDa}$ ), which is autocatalytically activated to chymosin (molecular mass $35.6 \mathrm{kDa}$ ).

In a previous work, a synthetic gene (chy) encoding the bovine chymosin was constructed (with codon usage optimized for Aspergillus) and expressed in A. awamori. The preprochymosin was synthesized in this fungus, with the release of the correct prochymosin that was self-processed yielding the mature chymosin [18]. During the optimization studies of heterologous proteins production in A. awamori, we observed that there is a bottleneck in the proper protein folding [12]. Other steps that occur during protein traffic through vesicles may also be limiting. Unfortunately, the vesicle targeting system and the final step in which the secretory vesicles are fused to the plasma membrane and release their content, is largely unknown. This step seems to be activated by fusogenic proteins [19].

We describe in this article that casein-derived phosphopeptides drastically stimulate the secretion of prochymosin. Expression analyses revealed that the stimulatory effect of these phosphopeptides is not exerted at transcriptional level. Proteomics analyses provided evidence of an important role of charged casein phosphopeptides (CPPs) in triggering the traffic of chymosin through the secretory pathway, which leads to the export of this and other extracellular proteins.

\section{Results}

Effect of casein on extracellular bovine chymosin production using five different recombinant strains

In initial studies, we observed that casein, which is partially hydrolyzed in the $A$. awamori cultures, exerts a strong stimulatory effect on chymosin production.

The stimulatory effect of casein on the secretion of bovine chymosin was studied using five A. awamori strains, which contain different expression cassettes for the chy gene (Figure 1A). Transformant T7-36 (reference strain), harbours a construction in which the complete pre-pro-chy gene is expressed from the constitutive promoter of the $A$. nidulans gpdA gene (PgpdA) [18]. The second strain (TA-9) carries a construction in which the pre-pro-chy gene is expressed from the $A$. oryzae amyB promoter. In the third strain (TAPL-4), the chy gene is also expressed from the $a m y B$ promoter, but the pre sequence of chymo$\sin$ has been replaced by the leader peptide ( 21 amino acids) of the A. oryzae AmyB protein in such a way that the sequence and all transcriptional signals of the $a m y B$ gene are retained together with the promoter. The fourth strain (TG-87) carries a construction in which the pre-prochy gene is expressed from the $A$. niger glucoamylase gene $($ gla $A$ ) promoter. The fifth strain (TGPL-10) bears a similar construction, with the exception of the leader peptide (pre sequence), which was that of the $A$. niger glucoamylase instead of that of pre-prochymosin.

In the above-mentioned constructions, transcription of the chy gene is terminated with the Tcyc1 (transcriptional terminator of the cytochrome oxidase gene) of Saccharomyces cerevisiae.

Production of extracellular chymosin by those strains was calculated in casein-supplemented medium (see below). Results showed that TAPL-4, in which the chy gene is expressed from the $A$. oryzae amyB promoter, yielded consistently higher levels of active extracellular chymosin than the other strains. There were no significant differences in the growth kinetics and the $\mathrm{pH}$ profiles among the five strains, except for the growth of TG-87, which was always a bit slower than the other strains (Figure 1B). 


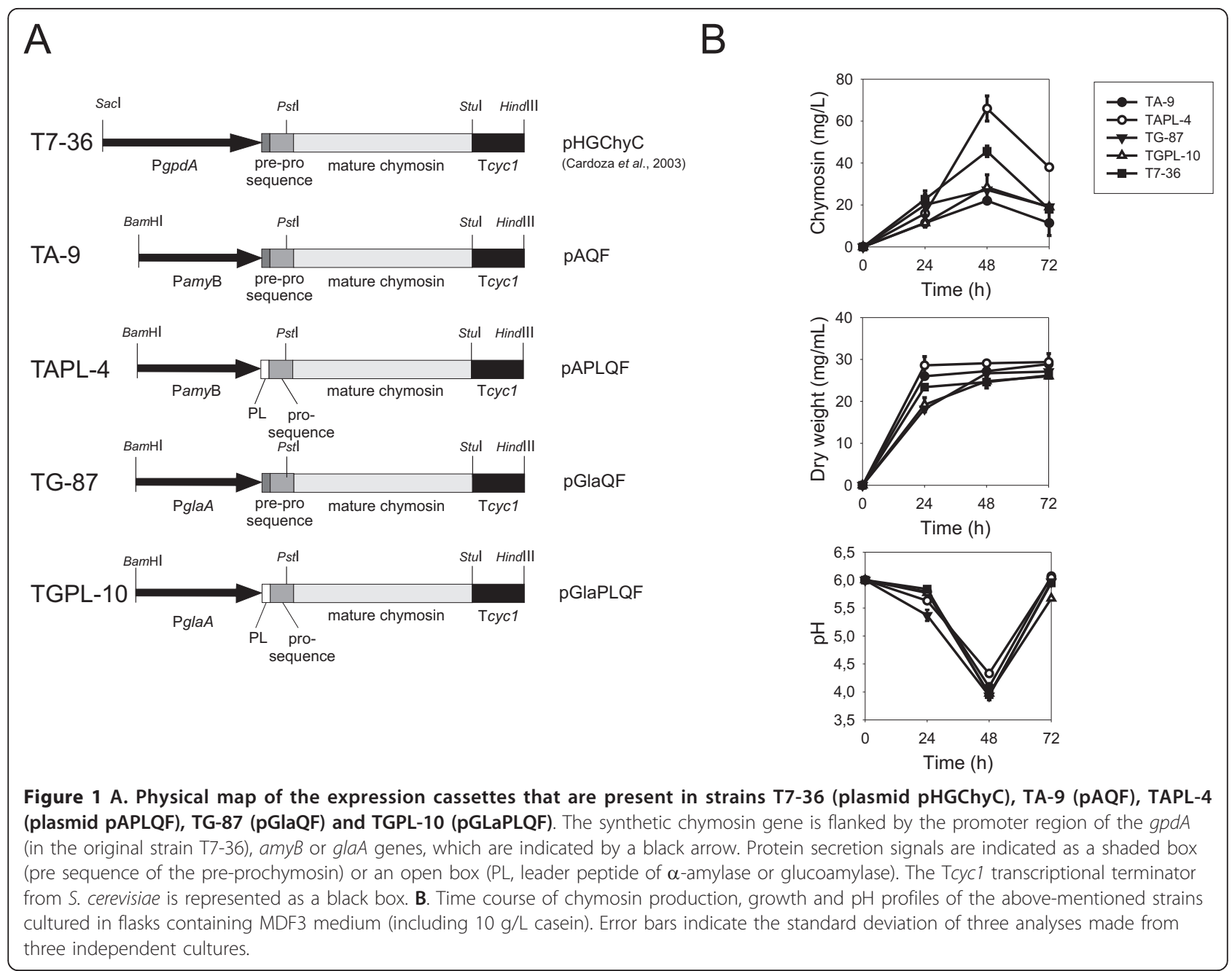

The secretion of chymosin is drastically increased upon the addition of casein to the culture médium

Experiments showed that the addition of casein $(10 \mathrm{~g} / \mathrm{L})$ to the culture medium is essential for chymosin secretion. Since the medium contains ammonium sulfate as nitrogen source, growth was not significantly affected by the addition of casein. Only between $0.36-0.72 \mathrm{mg} / \mathrm{L}$ of chymosin were secreted in the absence of casein, whereas those cultures supplemented with casein secreted chymosin at a concentration range from 23.04$46.08 \mathrm{mg} / \mathrm{L}$ (TG-87 strain) or $46.08-92.16 \mathrm{mg} / \mathrm{L}$ (TAPL4 and T7-36 strains) after $48 \mathrm{~h}$ of culture (Figure $2 \mathrm{~B}$ ). The same results were obtained with the addition of 5 g/L casein.

In order to test whether the casein effect was due to the casein protein itself or to the amino acids of this protein, the effect of casein was compared to that of casamino acids (casein hydrolysates) (Bacto ${ }^{\mathrm{TM}}$ ) and NZ Amino A (Sigma). Results indicated that strains TG-87 and TAPL-4 supplemented with casamino acids failed to increase the secretion of chymosin above $0.36-0.72 \mathrm{mg} /$ $\mathrm{L}$, although the medium with NZ Amino A gave rise to a slightly higher secretion (Additional File 1). Since casamino acids did not exert the stimulatory action, this effect seems to be due to the phosphopeptides existing in casein.

\section{Casein phosphopeptides stimulate chymosin secretion}

Casein is partially hydrolyzed to peptides by the proteolytic activities of A. awamori. An important fraction of casein peptides are the phosphopeptides. Evidence obtained with intestinal membranes indicates that CPPs trigger cytokine secretion [20]. Furthermore, CPPs elicited IL-6 cytokine release from cultured intestinal epithelial cells [21]. A similar secretion-enhancing mechanism may explain the stimulation of chymosin production in A. awamori. To test the effect of CPPs, cultures of $A$. awamori T7-36, TAPL-4 and TG-87 were grown in medium containing $10 \mathrm{~g} / \mathrm{L}$ CPPs (commercial CE90CPP obtained from DMV International). 


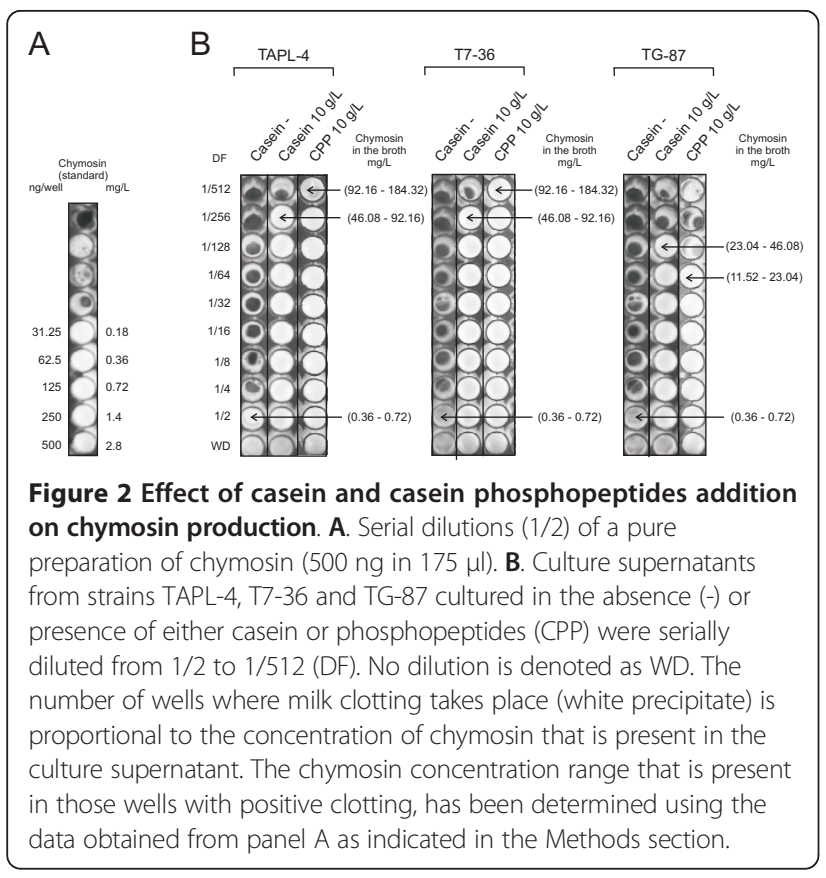

Growth parameters remained similar with or without CPPs. However, chymosin production reached the same levels (or even higher with strains TAPL-4 and T7-36) as those observed after casein addition (Figure 2B). The same results were obtained with the addition of $5 \mathrm{~g} / \mathrm{L}$ CPPs. Therefore, CPPs also stimulate the production of extracellular chymosin. This effect seems to be slightly stronger than that provided by casein.

Since CPPs are rich in phosphoserine (see Discussion), experiments were carried out as described above, but including $10 \mathrm{~g} / \mathrm{L}$ phosphoserine (Sigma-Aldrich). As it can be seen in Additional File 1, chymosin secretion levels remained similar to those obtained with the control (unsupplemented) samples, indicating that phosphoserine itself is not responsible for the positive stimulatory effect exerted by CPPs on chymosin production.

\section{Physiological parameters affected by the addition of either casein or CPPs}

In order to evaluate whether the effect caused by the addition of either casein or CPPs is an indirect consequence of adding a complex proteinaceous substrate and energy source, fermentations were carried out with the abovementioned strains in a Biostat B (Braun, Germany) fermentor $(5 \mathrm{~L})$. Parameters such as dry weight $(\mathrm{mg} / \mathrm{mL})$, $\mathrm{pH}$, dissolved $\mathrm{O}_{2}$ and the $\mathrm{CO}_{2}$ released were analyzed. All strains provided similar results and therefore, we chose the TAPL-4 strain as a model. In general, casein and CPPs provided the same response (Figure 3). Under control conditions (without the addition of either casein or CPPs), TAPL- 4 growth showed the same kinetic as in the presence of casein or CPPs, although biomass levels were slightly lower. Another interesting result was the lower levels of dissolved $\mathrm{O}_{2}$ (with the subsequent increase in the $\mathrm{CO}_{2}$ levels that were released) provided by the reference condition. The decrease in $\mathrm{pH}$ was also faster without the addition of casein or CPPs (Figure 3). These results indicate that casein and CPPs affect several cellular physiological aspects, specially those related to the use of oxygen (see Discussion).

\section{Dephosphorylation of casein decreases its effect on the chymosin production}

Since the stimulatory effect of casein on chymosin production might be due to phosphorylated peptides, we tested whether this effect was correlated to the casein phosphorylation rate. For this purpose, dephosphorylation of casein and CPPs was performed using the "antartic" alkaline phosphatase (New England Biolabs). The dephosphorylation efficiency was assessed by running SDS-PAGE gels, which were stained with ProQ (specific dye of phosphorylated peptides) and with blue-silver Colloidal Coomassie (unspecific stain). A large-scale alkaline phosphatase treatment of casein resulted in incomplete dephosphorylation, particularly of the high-molecular weight bands, which corresponded to the $\alpha \mathrm{S} 1$ and $\alpha \mathrm{S} 2$ subunits (Figure 4A). On the other hand, $\beta$ and $\kappa$ subunits were not visible after the specific ProQ staining, suggesting full dephosphorylation of these subunits.

Cultures of the TAPL-4 strain were carried out using MDFA3 medium supplemented either with $5 \mathrm{~g} / \mathrm{L}$ and $10 \mathrm{~g} / \mathrm{L}$ casein or with $5 \mathrm{~g} / \mathrm{L}$ partially dephosphorylated casein. Using $5 \mathrm{~g} / \mathrm{L}$ and $10 \mathrm{~g} / \mathrm{L}$ casein, a production of $69.1 \mathrm{mg} / \mathrm{L}$ was achieved after $48 \mathrm{~h}$ (Figure 4B), whereas using $5 \mathrm{~g} / \mathrm{L}$ partially dephosphorylated casein, the production of chymosin decreased to $46.08 \mathrm{mg} / \mathrm{L}$ at $48 \mathrm{~h}$. A second experiment was performed using commercially

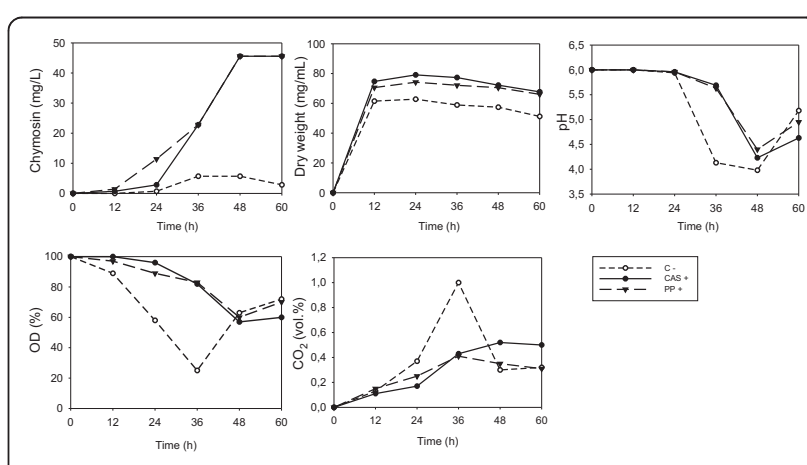

Figure 3 Physiological parameters obtained after the fermentation of the TAPL-4 strain in three identical 5-L Biostat B (Braun, Germany) fermentors. OD (\%): percentage of dissolved $\mathrm{O}_{2} ; \mathrm{CO}_{2}$ (vol.\%): percentage of released $\mathrm{CO}_{2}$. Casein (CAS +) or CPPs $(\mathrm{PP}+)$ were added at a concentration of $10 \mathrm{~g} / \mathrm{L}$. The reference condition (C-) did not contain casein or CPPs. 


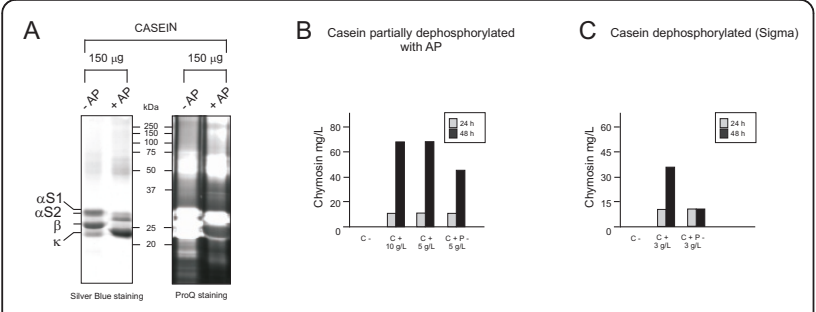

Figure 4 Dephosphorylation of casein with "antartic" alkaline phosphatase and effect of the dephosphorylated casein on chymosin secretion. A. SDS-PAGE (12\%) of casein and

dephosphorylated casein after alkaline phosphatase treatment. Four subunits of casein were detected after blue-silver Colloidal

Coomassie staining (left). ProQ Diamond Staining (rigth) showed a significant decrease in the signal intensity of the bands

corresponding to the dephosphorylated subunits of casein (subunits $\beta$ and $\kappa$ ) after treatment with "antartic" alkaline phosphatase (lane + AP). Tandem mass spectrometry was used to identify the casein subunits. B. Production of chymosin at 24 and $48 \mathrm{~h}$ in cultures without any addition, supplemented with $10 \mathrm{~g} / \mathrm{L}$ or $5 \mathrm{~g} / \mathrm{L}$ casein (C + ) or with $5 \mathrm{~g} / \mathrm{L}$ partially dephosphorylated casein (C+P-). C. Production of chymosin at 24 and $48 \mathrm{~h}$ using MDFA3 medium without supplement, supplemented with $3 \mathrm{~g} / \mathrm{L}$ casein, or with $3 \mathrm{~g} / \mathrm{L}$ commercially dephosphorylated casein (Sigma).

dephosphorylated casein (Sigma), which has a dephosphorylation degree of at least $70 \%$. As it can be observed in Figure $4 \mathrm{C}$, chymosin production at $48 \mathrm{~h}$ in those cultures supplemented with commercially dephosphorylated casein was clearly lower (less than 40\%) than in casein-supplemented cultures. In conclusion, it seems that the stimulatory effect of casein on chymosin production is largely due to CPPs.

Phosphorylated peptides similar to CPPs occur in other proteins, although they have not been studied in detail. Bovine seroalbumin (BSA), but not soy peptones, produces a similar effect in chymosin production. BSA (fraction V Sigma) exerted the same stimulatory effect as casein in the T7-36, TAPL-4 and TG-87 strains. This stimulatory effect was lower than that provided by casein after $24 \mathrm{~h}$. However, this effect increased at $48 \mathrm{~h}$, yielding high chymosin productions (up to $69.1 \mathrm{mg} / \mathrm{L}$ ) in the three strains (data not shown).

\section{Casein does not increase the transcription of the chy gene}

In order to test whether casein induces the expression of the chy gene, northern blot analyses were carried out. RNA samples from T7-36 and TAPL-4 strains were taken at 36 and $48 \mathrm{~h}$ from cells grown in the presence and absence of casein. In these strains, the chy gene is expressed from different promoters. Therefore, the possibility that casein induction was exerted at the transcription level seemed to be unlikely. A 736-bp DNA fragment that is internal to the chy gene, was used as probe. Another probe (834-bp) contained the A. nidulans $\beta$-actin gene, whose expression was used as a control of the RNA loaded in each lane. Northern blot analyses revealed that no significant differences were observed in the expression of the chy gene $(1.45-\mathrm{kb})$ either in the presence or absence of casein in the culture media (Figure 5). Similar results were obtained with CPPs (data not shown). Therefore, it can be concluded that casein or CPPs exert a positive effect on chymosin secretion, although they do not induce the expression of the chy gene.

\section{Western blot analysis shows an increased secretion of chymosin in casein-supplemented or CPPs-supplemented cultures}

If the effect of casein or CPPs is not exerted at the transcriptional level, it must be a consequence of a post-transcriptional event. To confirm this hypothesis, the culture supernatants of T7-36, TAPL-4 and TG-87 strains were analyzed by western blot using polyclonal antibodies raised against the bovine chymosin [18]. As shown in Figure 6A, those culture supernatants obtained after the addition of casein or CPPs showed an immunoreactive band with the same mobility as the authentic mature calf chymosin (35.6 $\mathrm{kDa}$ ). No immunoreactive bands with a size coincident with that of chymosin were detected in those supernatants that were obtained from control cultures. However, faint immunoreactive bands at high apparent molecular weight are visible for some samples (particularly in strain TAPL4). In order to ascertain whether these bands are related to casein, CPPs, chymosin or other proteins produced by the fungus, a negative control with non-inoculated casein/ CPPs-containing medium was made (Figure 6B). The MDFA3 "clean" medium itself or supplemented with either casein or CPPs did not show any band after western

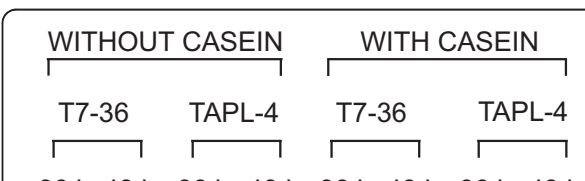

36 h 48 h 36 h 48 h 36 h 48 h 36 h 48 h

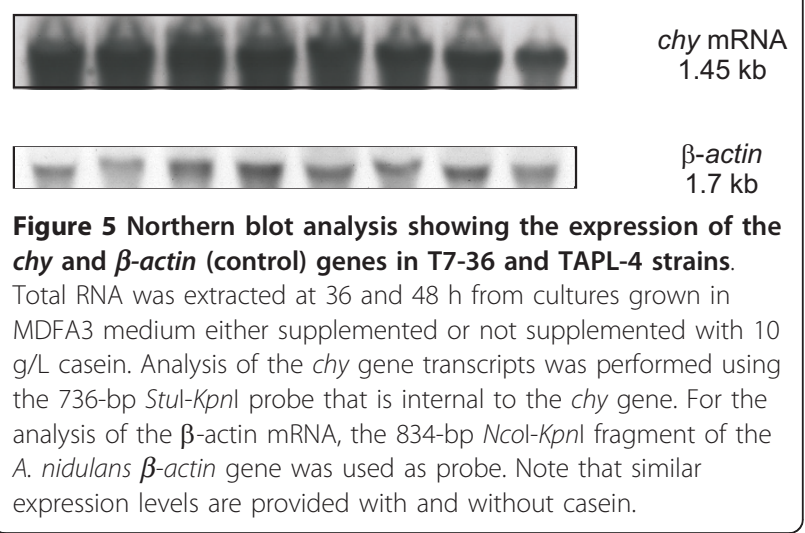




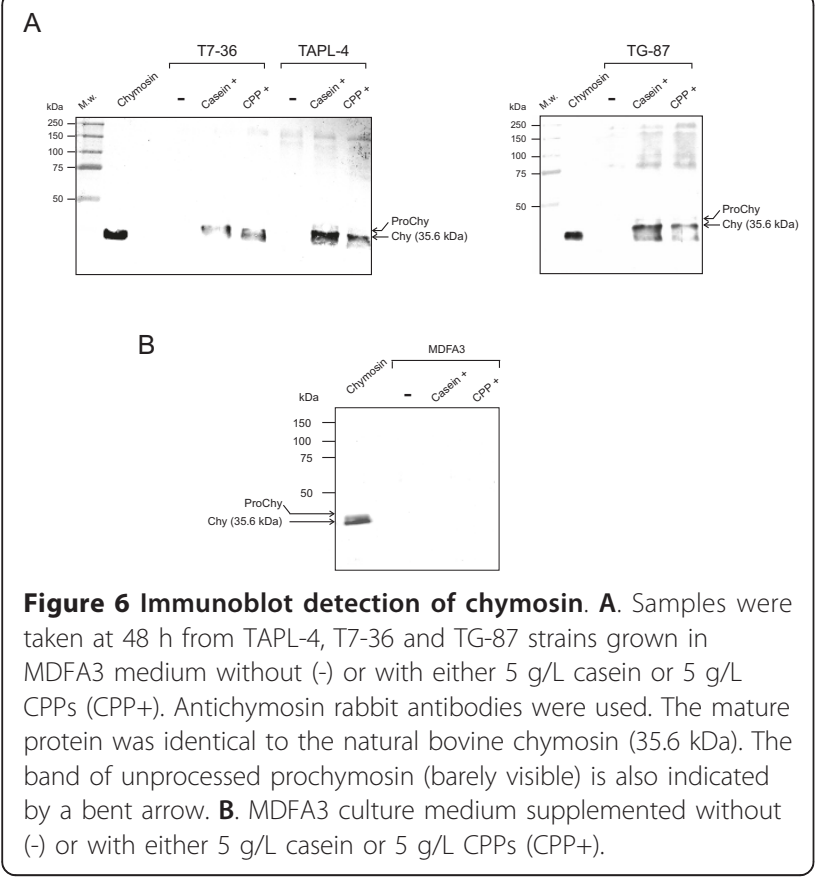

blot analysis. This suggests that those high-molecularweight bands may result from unspecific hybridization of the antichymosin antibodies with fungal proteins, although they most likely correspond to complexes of the unprocessed prochymosin form, as it was previously reported [18]. These results, taken together, confirm that casein or CPPs addition leads to an increase in the secretion of chymosin. This is in agreement with the increased clotting activity that was observed for the supernatants of either CPPs- or casein-supplemented cultures (Figure 2B).

\section{Effect of CPPs on the intracellular and extracellular proteomes of $A$. awamori}

Proteomics studies were conducted to seed light into the mechanisms that lead to the increased chymosin secretion after phosphopeptides addition. Both intracellular and extracellular protein fractions were analyzed by 2-DE and tandem MS in cultures with and without CPPs supplementation. Analysis of the intracellular proteome (Figure 7) showed that 75 spots (including 90 proteins) were downrepresented, whereas 13 spots (including 17 proteins) were overrepresented after the addition of CPPs (Additional File 2, Table S1 and Table S2).

The analysis of the extracellular proteome (Figure 8) revealed that only one spot (including one protein) was underrepresented, whereas 25 spots (28 proteins) were overrepresented after the addition of CPPs (Additional File 2, Table S3 and Table S4). This large increase in the abundance of extracellular proteins following the addition of CPPs is very interesting (see below). Proteins were grouped according to functional categories and the main findings are summarized below.

\section{Intracellular proteins differentially represented after the addition of CPPs Carbohydrate metabolism and energy}

Most of the proteins downrepresented in the CPPsupplemented culture were involved in carbohydrate metabolism and aerobic energy pathways. Some examples are provided by a putative mitochondrial aconitate hydratase (spots IC15, IC16 and IC20, An08g10530), a probable enolase (spot IC45, An18g06250), a probable phosphoglycerate mutase (spot IC49, An01g14090), a probable citrate synthase (spot IC50, An15g01920) a probable pyruvate dehydrogenase E1 component alpha subunit (spot IC51, An07g09530), a dihydrolipoamide acetyltransferase component of pyruvate dehydrogenase (spot IC57, An07g02180) or a triose-phosphate isomerase (spot IC63). In addition, a probable UTP-glucose-1-phosphate uridylyltransferase (An12g00820), which is involved in carbohydrate interconversion, is found in the control culture in spots IC40 and IC41, but not in CPPs-supplemented cultures. Alcohol utilization (oxidation) proteins, like mannitol 2-dehydrogenase (spot IC38, An03g02430), alcohol dehydrogenase (spot IC58, An02g02060) or aldehyde dehydrogenase (spot IC43) were downrepresented in the supplemented cultures.

Interestingly, it seems that in cultures supplemented with CPPs, the metabolic fluxes were diverted to the anaerobic fermentative pathway. This is supported by the finding of a probable acetaldehyde-forming pyruvate decarboxylase (spot IP2, An02g06820) and three isoforms of the fermentative ADH1 alcohol dehydrogenase (spots IP8, IP9 and IP10), which are highly overrepresented after CPPs supplementation. This suggests that there is a limitation in the oxygen available in those cultures grown in the presence of phosphopeptides (see below), which leads to the conversion of glucose into ethanol by these enzymes. Glyceraldehyde-3-phosphate dehydrogenase (spot IP11) is another interesting protein overrepresented after phosphopeptides addition. Besides its key role in glycolysis, a number of roles have been reported for this enzyme, including modulation of the cytoskeleton, phosphotransferase/kinase activity, and the fusogenic activity involved in vesicle fusion [19,22-24]. All these activities are essential for the maintenance of normal secretory functions and indeed, it has been demonstrated that glyceraldehyde-3-phosphate dehydrogenase is required for vesicular transport from the ER to Golgi in the early secretory pathway [25]. Therefore, CPPs may play an important role in the stimulation of the protein secretion pathaway.

\section{Amino acid and nitrogen metabolism}

The finding that two different proteins with the same putative function are alternatively overrepresented under each condition is remarkable. This is the case of a putative 


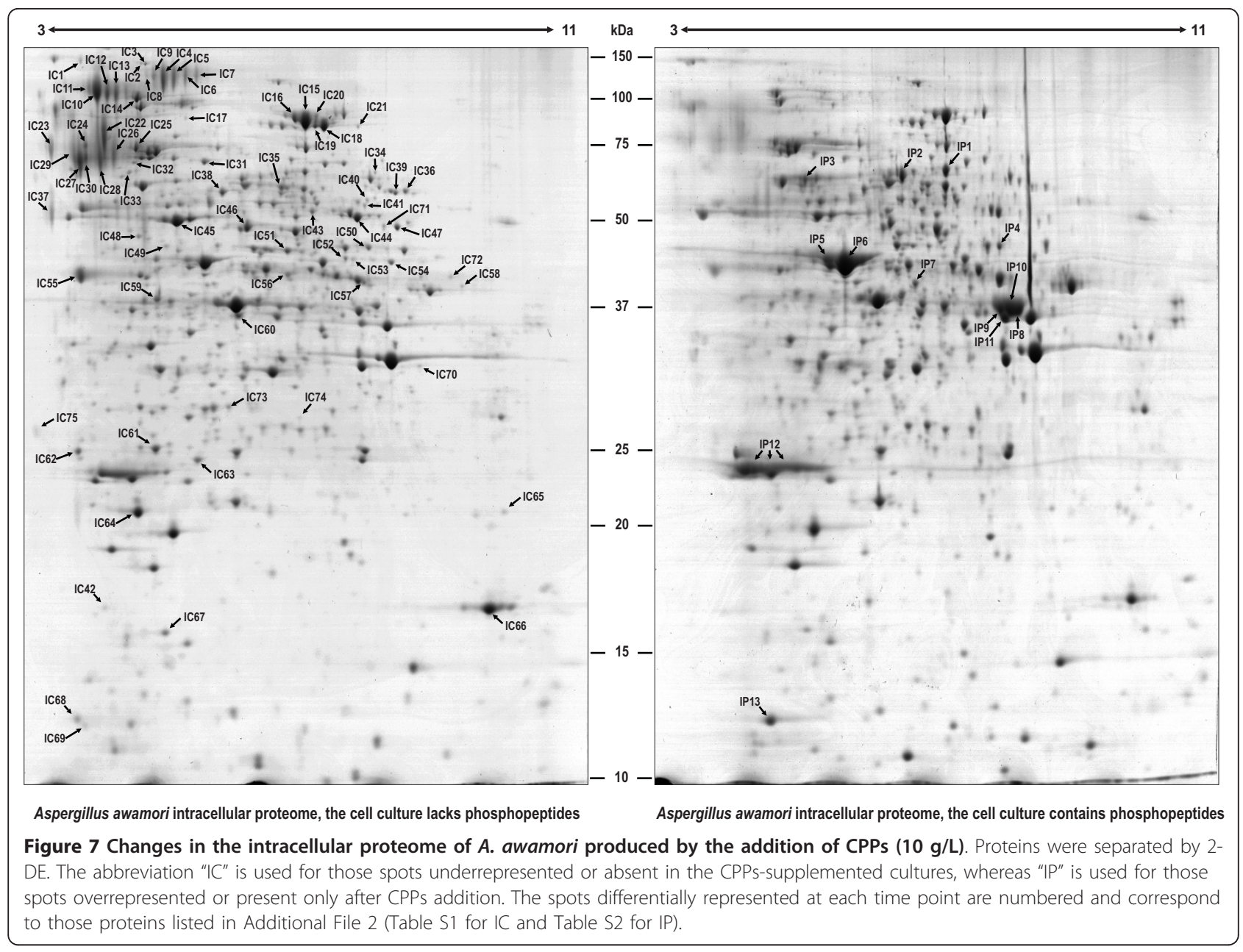

aspartate transaminase, which is only present in the control cells (spot IC58, An04g06380) and in spot IP4 (An16g05570), which is 5-fold overrepresented in CPPssupplemented cells. Whether the function of these two protein forms is exactly the same, is unknown. Several amino acid biosynthetic enzymes decreased in CPPs-supplemented cells; e.g. homoaconitate hydratase. This enzyme of the fungal lysine biosynthetic pathway is only detected in the control cells (spot IC17, An15g00350) (Figure 7). The NADP-dependent glutamate dehydrogenase (spot IC46), which converts glutamate to $\alpha$-ketoglutarate and vice versa, is 1.81 -fold downrepresented in the CPPs-supplemented cells. All these changes are consistent with a decrease of primary metabolism as a consequence of the detection of CPPs availability.

\section{Other metabolic pathways}

A probable S-adenosylmethionine synthetase (An08g02700) is only detected in control cultures (spot IC70). This enzyme catalyzes the formation of S-adenosylmethionine, which is an important methyl donor for transmethylations and is also the propylamino donor in polyamine biosynthesis. One of the pathways where S-adenosylmethionine acts as a methyl donor is the ubiquinone biosynthesis. In this pathway, a molecule of 4-hydroxybenzoate undergoes a prenylation, a decarboxylation and three hydroxylations alternating with three methylation reactions, resulting in the formation of coenzyme Q [26]. Interestingly, a putative 3polyprenyl-4-hydroxybenzoate decarboxylase, which is involved in the biosynthesis of this coenzyme, is 10.7-fold overrepresented in the cultures supplemented with phosphopeptides.

\section{Nutrient acquisition}

A global overview of the proteins that are downrepresented or fully absent in the intracellular proteome of CPPs-supplemented cultures shows that pre-enzymes related to nutrient acquisition are more abundant in the intracellular fraction of control cells, specially several probable acid phosphatases, phosphoesterases and phytases (spots IC4-IC9, aphA; spots IC10-IC12, An08g0985; spot IC13, An18g04140; spots IC22, IC26 and IC28, An01g14940; spots IC29 and IC30, phyB; spots IC37 and IC42; An12g10630) (Figure 7). This suggests that when phosphopeptides are added, the intracellular concentration of these enzymes is decreased due to enhanced secretion 


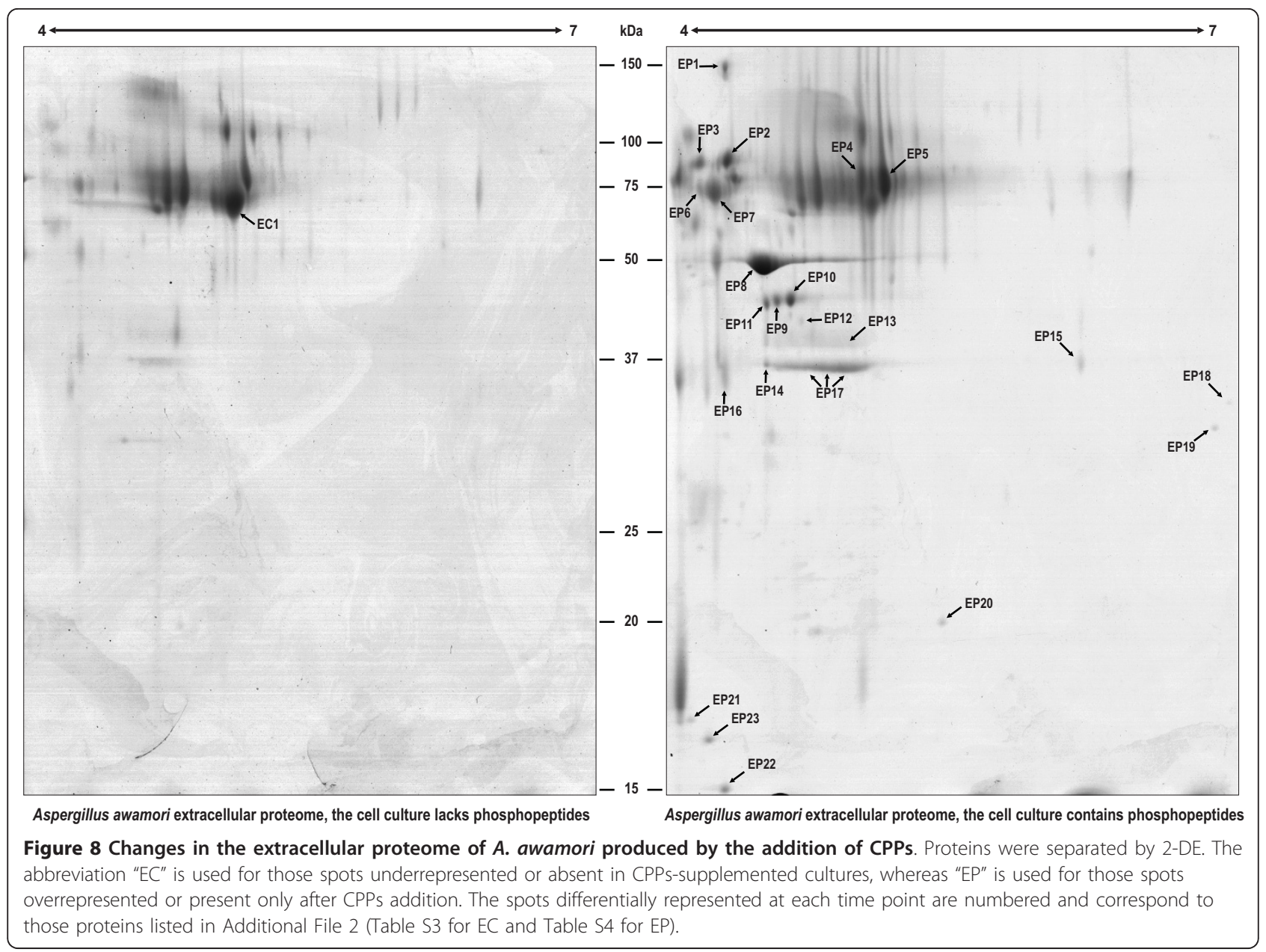

(see below). Glucoamylase, an abundant enzyme in $A$. awamori, which hydrolyzes 1,4-alpha- and 1,6-alpha-glucosidic linkages in starch yielding glucose, is detected in the intracellular protein extracts of control cultures, but is absent in CPPs-supplemented cells (spots IC11, IC12 and IC13). The alpha-galactosidase (hydrolysing $\alpha$-1,6-linked galactose residues from oligomeric compounds) is also downrepresented in intracellular extracts of CPPs-supplemented cells (spots IC22, IC24, IC29 and IC30). These results suggest that glucoamylase and galactosidase are depleted from the cytoplasm by increasing their secretion in a mechanism mediated by phosphopeptides.

Correlated to this, is the finding that the protease pepE (spot IC55) and one probable oligopeptidase (spot IC65, An16g08150) are also downrepresented in CPPstreated cells.

\section{Protein folding, modification and targeting}

It is known that overproduction of recombinant proteins in eukaryots induces the overexpression of genes encoding several chaperones including $\mathrm{BiP}$, a chaperone of the heat shock protein (HSP-70) family [12,27]. We found that several chaperones of the heat shock protein family (spots IC2 and IC3, An01g13220; spots IC25 and IC74, An07g09990; spots IC32, IC33 and IC48, An16g09260) and the cyclophilin-like peptidyl prolyl cis-trans isomerase, which accelerates protein folding (spot IC66) and a Hsp90 binding co-chaperone (spot IC62, An14g05320), are underrepresented or even absent in the CPPs-supplemented cultures. In addition, the lectin chaperone calnexin (spot IC24, An01g08420) was detected under control conditions, but absent in CPPs-supplemented cultures. Phosphopeptides reduce the levels of the above-mentioned proteins, probably reflecting a more efficient system of protein secretion that reduces the unfolded proteins and the need for chaperones.

\section{Response to stimuli}

Oxidative stress response proteins are more abundant in control cultures than in CPPs-supplemented ones. These include catalase-peroxidase (spots IC17, IC18 and IC19, An01g01830; spot IC39, An02g02750), a mitochondrial peroxiredoxin PRX1 (spot IC63, An04g03360) and a cytochrome C peroxidase Ccp1 (spot IC73, An04g04060). This 
decrease of the oxidative stress proteins correlates with the change in aerobic/fermentative metabolism (see Discussion).

\section{Regulatory proteins}

A probable transcriptional repressor TupA/RocA, which represses asexual development and yeast cell morphogenesis [28], is only detected under control conditions but not in CPPs-supplemented cultures (spot IC57, An15g00140) (Figure 7). Another transcriptional NmrA-like repressor (spot IC60, An15g02410) was found underrepresented in CPPs-supplemented cells. NmrA is an Aspergillus nidulans negative transcriptional regulator involved in modulating the activity of the transcription factor AreA [29,30], which is responsible for nitrogen metabolite regulation $[31,32]$.

\section{Extracellular proteins differentially represented after the addition of CPPs}

Proteins in the culture medium (the secretome) were compared with and without CPPs supplementation (Figure 8).

\section{Cell wall biosynthetic proteins}

After phosphopeptides addition, several proteins involved in cell wall synthesis were found overrepresented in the extracellular fraction. This is the case of 1,3-beta-glucanosyltransferases An09g00670 (spot EP3) and An10g00400 (spots EP9, EP10 and EP11). The same was observed for spot EP2, a putative 1,3-beta-glucanosyltransferase [33] that did not match any of the $A$. niger predicted proteins present in databases (although it may be present in the genome of $A$. awamori). These enzymes are well known to be secreted through vesicles that are fused to the cytoplasmic membrane. Other enzymes important for proper cell wall ultrastructure and organization that were overrepresented in the extracellular fraction after phosphopeptides addition were a GPI-anchored cell wall organization protein Ecm33 (spots EP6 and EP7, An04g01230) and a GPIanchored cell wall beta-1,3-endoglucanase EglC (spot EP16, An03g05290).

\section{Proteolytic proteins and allergens}

As described above, CPPs addition drastically increases the secretion of the heterologous protein chymosin. Spot EP17 (a band that was analyzed in three different positions and corresponds to chymosin) is 6.46-fold overrepresented in CPPs-supplemented cultures compared to control cultures. Two other minoritary forms of this protein (spots EP13 and EP14) and spots EP12 (aspartic protease pepE) and EP19 (serine proteinase pepC), were only detected under CPPs-supplemented conditions.

Another interesting protein secreted after the addition of phosphopeptides is a probable allergenic cerato-platanin Asp-F13 (An02g01550), which is detected in spots EP21, EP22 and EP23. This protein was described in the ascomycete Ceratocystis fimbriata [34].

\section{Nutrient acquisition}

Two isoforms of the alpha-galactosidase were found overrepresented after phosphopeptides addtion (spots EP4 and EP5). This protein was underrepresented in the intracellular proteome of CPPs-supplemented cells. The alphaAmylase was only detected in the extracellular proteome of CPPs-supplemented cultures (spot EP8) and represents the spot with the higher intensity, thus confirming the beneficial effect of phosphopeptides on protein secretion. Since $\alpha$-amylase is an endogenous $A$. awamori protein (encoded by the duplicated $a m y A$ and $a m y B$ genes) it is concluded that the stimulatory effect of CPPs on the secretion of proteins is common for homologous and heterologous proteins.

The only extracellular protein found underrepresented in the extracellular proteome of CPPs-supplemented cells is a probable phosphoesterase (spot EC1, An01g14940). Strikingly, another isoform of the same protein was only found after phosphopeptides addition (spot EP4), suggesting that CPPs addition causes a modification of this protein.

\section{Discussion}

CPPs are fragments of casein that are rich in phosphoserine $[35,36]$. They are formed by partial hydrolysis of casein by the $A$. awamori proteases. These phosphoserine residues bind calcium and indeed, CPPs increase the intestinal absorption of calcium in rats $[37,38]$. Further characterization of the CPPs led to the isolation of $\beta$-casein(1-25) and $\alpha$-casein(59-79) (the numbers in parenthesis correspond to the amino acids in the casein subunits), two peptides rich in phosphoserine with immunomodulating activity [39-41]. Phosphoserine itself, however, was not able to increase the secretion of chymosin, indicating that the secretory pathway is induced by the phosphorylated peptides that are present in CPPs, rather than by a specific phosphorylated amino acid.

Secretion of heterologous proteins in fungi is a subject of great interest because they are usually secreted with a 10 to 100 -fold lower efficiency than homologous proteins $[8,13,42]$. The reasons for these differences appear to be related to the low adaptation of the heterologous proteins to the characteristics of the fungal secretory pathway. Endogenous proteins seem to be better adapted. For this study, we have used the secretion of bovine chymosin as a model. Surprisingly, we found that CPPs (or casein) drastically stimulate (from 40 to 80 -fold depending on the strains and culture conditions) the production of extracellular chymosin. This effect was not exerted by casamino acids (fully hydrolyzed casein) or by the ammonium salts used as nitrogen source for growth.

Northern analysis of the expression of the chy gene from two different promoters $(g p d A$ or $a m y B)$ revealed that CPPs do not significantly change the transcription 
of the chy gene. However, western blot analysis confirmed the increased secretion of chymosin (prochymosin and mature chymosin forms) following the supplementation with CPPs.

It is well known that CPPs elicit the secretion of lymphokines in cultures of intestine epithelial cells [21]. It has also been reported that CPPs inhibit gastric secretion probably by reaching target sites (e.g. receptors, enzymes) at the luminal site of the gastrointestinal tract [43]. However, the mechanisms involved are not known. Therefore, we have investigated the proteomics of the cellular response to CPPs addition. The proteomics studies revealed major changes in the A. awamori metabolism, particularly in the depletion of pre-enzymes in the intracellular proteome and large increases in the representation of many extracellular proteins in the secretome.

One of the primary changes observed, was the cellular response to oxygen. Several oxidative stress response proteins (catalase and peroxidase) are underrepresented in the proteome of CPPs-supplemented cells. Oxidative stress and the occurrence of reactive oxygen species are common to aerobically living organisms. However, during fermentation studies we also showed that the dissolved $\mathrm{O}_{2}$ levels present in the culture medium were higher after CPPs addition, which indicates that there is a limitation in the use of oxygen by the cell, probably due to changes in membrane permeability. Proteomics studies also suggested that in cultures supplemented with CPPs, the metabolic fluxes were diverted to the anaerobic fermentative pathway. This is supported by the overrepresentation in CPPssupplemented cultures of a protein similar to the bacterial hemoglobin (spots IP5 and IP6). A major problem in industrial fermentations with $A$. awamori is to ensure sufficient oxygen supply, which is required for respiratory metabolism. This is the reason why in the case of oxygen limitation, the fungus will produce various by-products, such as reduced organic acids and alcohols. It has been reported that the overexpression of the gene encoding a bacterial hemoglobin from Vitreoscilla in Acremonium chrysogenum or in A. niger leads to a relief of stress when the transformants were exposed to oxygen limitation $[44,45]$. These hemoglobin proteins enhanced the production of alpha-amylase by the yeast Schwanniomyces occidentalis [46]. CPPs may produce a similar effect by increasing the concentration of the endogenous $A$. awamori hemoglobin-like protein.

There is also a significant change in sugar metabolism. We found in CPPs-supplemented cells a decrease in several enzymes related to glycolysis and citric acid cycle (phosphoglycerate mutase, citrate synthase, mitochondrial aconitate hydratase, among others), whereas there is an increase in several enzymes that catalyze the conversion of pyruvic acid to ethanol (e.g. pyruvate decarboxylase [forming acetaldehyde] and three isoforms of the alcohol dehydrogenase).

A noteworthy change is that of the glyceraldehyde-3phosphate dehydrogenase, which is overpresented in the proteome of CPPs-supplemented cells. This enzyme has been reported to play several roles in metabolism including a vesicle fusogenic activity and a cytoskeleton-modulation phosphotransferase/kinase activity [19,22-24]. Therefore, it has been included in the group of "moonlighting proteins", a designation for the collective of proteins with two or more unrelated functions that are widespread among organisms ranging from bacteria to mammals $[47,48]$. This primarily intracellular protein has been reported to be secreted by a non-conventional system in the fungus Penicillium chrysogenum [49]. The exact mechanism of glyceraldehyde-3-phosphate dehydrogenase that is related with cytoskeleton extension and vesicle traffic is still unknown. However, a role of this protein in the secretory protein traffic through vesicles is likely, probably by facilitating vesicle targeting to appropriate cell membrane locations and fusion to the cell membrane.

Our results show a very clear effect of CPPs on depletion of pre-enzymes from the intracellular space and on their release to the extracellular medium. Several proteins involved in cell-wall biosynthesis that are targeted to and released at the tip of the hyphae, are overrepresented in CPPs-supplemented cells. In Neurospora crassa, vesicles aimed for fusion at the growing hyphal tip show high concentration near the apex (0 to $5 \mu \mathrm{m})$. However, they exponentially decline at increasing distances from the tip [50]. An organellar $\mathrm{Ca}^{2+}$ gradient concentration, which is required for hyphal tip growth, occurs in the hyphal tip region $[51,52]$. CPPs are known to form complexes with $\mathrm{Ca}^{2+}$ and this may be the molecular mechanism of their action on vesicle-mediated secretion of cell-wall related enzymes.

Another large group of extracellular proteins overrepresented in CPPs-supplemented cultures include $\alpha$ amylase and extracellular proteases. A member of this group is the heterologous chymosin that shows several isoforms with the same molecular mass but with different charge in the secretome 2D gels. Two minoritary secreted chymosin forms with slightly larger molecular mass correspond to pro-chymosin forms. It is noteworthy that the intracellular pre-enzyme forms of several extracellular enzymes detected in the proteome of control cells are absent or greatly reduced in the intracellular proteome of CPPs-supplemented cells, confirming the enhanced secretion of these proteins. The secretion of $\alpha$ amylase (the majoritary protein in extracellular extracts), is also enhanced in the CPPs-supplemented cultures, indicating that the stimulation of the secretion is a 
general mechanism that affects both minoritary and abundant proteins.

\section{Conclusions}

Our results indicate that CPPs trigger a signaling cascade that changes the carbohydrate metabolism, oxygen utilization and the activity of the secretory pathway. It is noteworthy that some overrepresented proteins in the secretome of CPPs-supplemented cultures are extracellular enzymes, which are targeted to the hyphal tips. On this location, they fuse to the cell membrane releasing the active enzymes. This work provides a background for important improvements of valuable heterologous protein secretion in filamentous fungi.

\section{Methods}

\section{Microorganisms and culture conditions}

A. awamori lpr66, a strain deficient in aspergillopepsin A [42] was used as the host strain for transformation with expression vectors containing the chy gen. E. coli DH5 $\alpha$ was used for plasmid amplification.

A. awamori transformants were grown on solid medium for sporulation as previously described [18]. The defined MDFA3 chymosin production medium contained: $10 \mathrm{~g} / \mathrm{L}$ glucose; $20 \mathrm{~g} / \mathrm{L}$ starch; 10,57 g/L ammonium sulfate; $144 \mathrm{~mL}$ salts II $\left(104 \mathrm{~g} / \mathrm{L} \mathrm{K}_{2} \mathrm{HPO}_{4} ; 102 \mathrm{~g} / \mathrm{L} \mathrm{KH}_{2} \mathrm{PO}_{4} ; 5,08\right.$ $\left.\mathrm{g} / \mathrm{L} \mathrm{Na}_{2} \mathrm{SO}_{4}\right)$ and $144 \mathrm{~mL}$ salts III $\left(2,4 \mathrm{~g} / \mathrm{L} \mathrm{MgSO}_{4} \cdot 7 \mathrm{H}_{2} \mathrm{O}\right.$; $0,2 \mathrm{~g} / \mathrm{L} \mathrm{ZnSO}_{4} \cdot 7 \mathrm{H}_{2} \mathrm{O} ; 0,2 \mathrm{~g} / \mathrm{L} \mathrm{MnSO}_{4} \cdot 7 \mathrm{H}_{2} \mathrm{O} ; 0,05 \mathrm{~g} / \mathrm{L}$ $\mathrm{CuSO}_{4} \cdot 5 \mathrm{H}_{2} \mathrm{O}$ and $0,37 \mathrm{~g} / \mathrm{L} \mathrm{CaCl}_{2}$ ). This medium was inoculated with $9 \%$ of seed culture [18] and cultures were grown at $30^{\circ} \mathrm{C}$ and $250 \mathrm{rpm}$ for $48 \mathrm{~h}$ in a rotary shaker (Model 481 Console incubator/refrigerated shaker, Thermo Scientific). MDFA3 was supplemented with different compounds as explained in the Results section.

For A. awamori fermentations, seed cultures (9\%) were used to inoculate three 5-L Biostat B (Braun, Germany) fermentors, which contained $3 \mathrm{~L}$ of defined MDFA3 medium without or with the presence of either $10 \mathrm{~g} / \mathrm{L}$ casein or $10 \mathrm{~g} / \mathrm{L} \mathrm{CPPs}$. The fermentations were run at $30^{\circ} \mathrm{C}$ and $300 \mathrm{rpm}$ with an air flow of $2,5 \mathrm{~L} / \mathrm{min}$. The agitation speed was increased to $350 \mathrm{rpm}$ at $24 \mathrm{~h}$ and $500 \mathrm{rpm}$ at $36 \mathrm{~h}$.

\section{Plasmid construction for chy gene expression and transformation of $A$. awamori}

For the construction of pGlaQF, a 1146-bp fragment corresponding to the coding region of the preprochymosin, was synthesized by PCR using primers PreQ1 (5'CGC TGC CTG GTC CTG CTG GCC3') and TQ3 (5'TCA AAT GGC CTT GGC CAG ACC GAC3'). Plasmid pANPPQ carrying the complete cassette of the chy gene under the gpdA promoter, was used as template [18]. Next, DNA was digested with KpnI, giving rise to a 450bp fragment that was ligated to plasmid pJL43b7 (kindly provided to us by S. Gutiérrez, University of León, Spain), which contains the $A$. niger gla gene promoter fused to the ble gene (for phleomycin resistance) and the S. cerevisiae cyc1 transcriptional terminator. This plasmid was previously digested with $\mathrm{NcoI}$, blunt-ended with Klenow and digested with KpnI. The resultant plasmid, pJL43bq, carries the glaA promoter fused to the pre-prochymosin sequences and part of the chy gene. Then, p84AB (kindly provided to us by R.E. Cardoza, University of León, Spain), was digested with $K p n I$, giving rise to a fragment of 1045 bp containing the last $700 \mathrm{bp}$ of the chy gene fused to the $S$. cerevisiae $c y c 1$ gene transcriptional terminator. This fragment was ligated to the KpnI site of pJL43bq to obtain pGlaQ, which bears the complete chymosin expression cassette under the control of the glaA promoter. pGlaQ was digested with BamHI and HindIII and the chymosin expression cassette was inserted into pJL43b1 (containing a phleomycin resistance cassette: PgpdA::ble::Tcyc) [53], wihch was digested with the same enzymes resulting in the final plasmid pGlaQF.

The $a m y B$ promoter (800-bp) was obtained from plasmid pTAex3 [54] after BamHI digestion. Then, it was subcloned into pBluescript SK+ (digested with the same enzyme), thus giving rise to plasmid pTA16. Simultaneously, a 1146-bp PCR fragment containing the preprochymosin, was generated using two oligonucleotides; ProQ1 (5'GCC GAG ATC ACC CGC ATC CCC CTG3') and TQ3 (5'TCA AAT GGC CTT GGC CAG ACC GAC3'). Plasmid pANPPQ was used as template. After digestion with ClaI, a 917-bp fragment was introduced into the SmaI-ClaI-digested pTA16, obtaining plasmid pTAmy, which carries the $a m y \mathrm{~B}$ gene promoter fused to pre-pro sequences of the chy gene (it also includes a fragment of the chy gene). The final part of the chy gene and $\mathrm{T} c y c 1$ were excised from ClaI-digested $\mathrm{pGlaQ}$, giving rise to a 538 bp fragment, which was ligated to the ClaIdigested pTAmy to obtain pAQ. The complete expression cassette of the chy gene under the control of $a m y \mathrm{~B}$ promoter was then ligated as a BamHI-HindIII fragment to the phleomycin resistance cassette, which was obtained from $\mathrm{pGlaQF}$ (excised with the same enzymes), thus giving rise to plasmid $\mathrm{pAQF}$.

To obtain plasmid pGlaPLQF, PCR was first performed using plasmid pThIX as template [55]. It contains the glaA gene promoter and its leader peptide. Primers PGLA (5'TTT GGA TCC GAA CTC CAA TCG GGG GGA3') and phopshorylated PLGLA2-P (5'TGC CAA CCC TGT GCA GAC GAG GCC3') were also used. The 854-bp product carrying the glaA gene promoter and its leader peptide was digested with BamHI. The coding region of the prochymosin was obtained by PCR using PANPPQ as template and primers PROQ2-P (5'GCC GAG ATC ACC CGC ATC CCC CTG3') and TQ3 (see above). The 1098bp amplified product was digested with $\mathrm{ClaI}$ to obtain the 
fragment carrying the coding region of the pro sequence of the chy gene (it also includes a fragment of the chy gene). These two PCR products that were previously digested, were ligated to the $\mathrm{pGlaQ}$ vector, which was digested with $B a m \mathrm{HI}$ and ClaI to give rise to pGlaPLQ. Next, pGlaPLQ was digested with BamHI and HindIII. This fragment was inserted into pGlaQF (containing a phleomycin resistance cassette) previously digested with the same enzymes, to obtain pGlaPLQF.

For the construction of pAPLQF, the region including the $A$. oryzae $a m y B$ gene promoter and its leader peptide, was amplified with primers PAMY2 (5'TTT TGG ATC CCC ATC ATG GTG TTT TGA T3') and phopshorylated PLAP (5’AGC CAA AGC AGG TGC CGC GAC CTG3'). Genomic DNA from A. oryzae was used as template. The 680-bp fragment amplified by PCR was digested with BamHI. The coding region of the prochymosin was obtained by PCR using PANPPQ as template and primers PROQ2-P and TQ3 (see above). This fragment was also cut with ClaI. These two PCR products previoiusly digested, were ligated to $\mathrm{pGlaQ}$, digested with $\mathrm{BamHI}$ and ClaI to generate pAPLQ. Finally, pGlaQF was digested with BamHI and HindIII and ligated to the BamHI and HindIII fragment of pAPLQ, which corresponds to the complete chymosin expression cassette with the $a m y B$ gene promoter and its leader peptide, thus giving rise to plasmid pAPLQF.

Plasmids were introduced into A. awamori by transformation as described by Cardoza and co-workers [18].

\section{RNA Isolation and Northern Hybridizations}

Total RNA was isolated as described by Chomczynski and Sacchi [56] from frozen mycelium that was disrupted by grinding it in a mortar previously refrigerated with liquid nitrogen. The disrupted cells ( 0.5 to $1 \mathrm{~g}$ ) were mixed with $1.3 \mathrm{ml}$ of the EFA solution containing equal volumes of phenol and extraction buffer (4 M guanidinium thiocyanate, $0.5 \%(\mathrm{w} / \mathrm{v})$ lauryl sarcosine and $25 \mathrm{mM}$ sodium citrate, $\mathrm{pH} 7.0)$. Seven $\mu \mathrm{l}$ of $\beta$-mercaptoethanol were added for each $\mathrm{mL}$ of extraction buffer. The mixture was centrifuged at top speed in a microcentrifuge for $5 \mathrm{~min}$ and the supernatant was mixed with $130 \mu$ l chloroformisoamyl alcohol (CIA) (24:1, vol/vol). The mixture was centrifuged again and the supernatant was purified by phenol-CIA and CIA extractions. One-half volume of $8 \mathrm{M}$ $\mathrm{LiCl}$ was added to the clarified supernatant and precipitated overnight at $4^{\circ} \mathrm{C}$. RNA was recovered by centrifugation, washed with $70 \%(\mathrm{v} / \mathrm{v})$ ethanol and resuspended in Milli-Q water. Northern hybridizations were performed according to Sambrook and Russell [57]. Probes were internal to the synthetic chy gene (StuI-KpnI fragment) and to the $\beta$-actin gene of A. nidulans (NcoI-KpnI fragment).

\section{SDS-Electrophoresis and western blotting}

SDS-Electrophoresis and western blotting were carried out as previously described [18]. For phosphoprotein detection, SDS-PAGE gels were stained with Pro-Q Diamond gel dye according to the modified protocol of Eymann and co-workers [58]. Gels were scanned using the FCA 5000 FujiFilm reader (Excitation source: $532 \mathrm{~nm}$ laser, longpass emission filter: $555 \mathrm{~nm}$ ) with a resolution of 50 micron.

\section{Milk-Clotting Assay and Chymosin Quantification}

Chymosin was quantified by milk clotting. Serial dilutions $(1 / 2)$ of a pure preparation of chymosin (500 ng) were prepared in a 96-well microtiter plate. Each well contained $175 \mu \mathrm{l}$. The number of wells where milk clotting takes place (white precipitate) is proportional to the concentration of chymosin. The minimal dilution that produces milk clotting in the assay is the fourth chymosin dilution (1/16), which corresponds to 31.25 ng chymosin $(500 / 16=$ $31.25)$. This amount of chymosin corresponds to a concentration of $0.18 \mathrm{mg} / \mathrm{L}(31.25 \mathrm{ng}$ chymosin/175 $\mu \mathrm{l})$. Therefore, for the quantification of the chymosin produced by different strains of $A$. awamori, serial dilutions $(1 / 2)$ of the culture broths were prepared. Then, 0.18 was multiplied by the corresponding dilution that produces clotting in each assay. Due to the steps in sample dilution, estimation of chymosin production cannot be strictly exact and therefore, production was expressed as the range of concentrations corresponding to two consecutive dilutions (i.e.: if the last dilution of culture supernatants that provides clotting activity is $1 / 256$, the estimated concentration of chymosin would range from $46.08 \mathrm{mg} / \mathrm{L}$ $[0.18 \times 256]$ to $92.16 \mathrm{mg} / \mathrm{L}[0.18 \times 512])$. We always consider the lowest amount (i.e. 46.08) as the coagulationpositive activity because the following dilution step does not give rise to clotting reaction.

\section{Protein extraction protocol for proteomics studies- A. awamori}

TAPL-4 (see Results) was grown as previously described [18]. Briefly, this strain was grown for sporulation at $30^{\circ} \mathrm{C}$ for 3 days on Power solid medium, which was obtained by mixing 1:1 (v/v) standard Czapek medium and PM1 medium (30 g lactose, 5 g Bacto Peptone, 0.5 g corn steep solids, $4 \mathrm{~g} \mathrm{NaC1}, 1 \mathrm{mg} \mathrm{CuSO} \cdot \cdot 7 \mathrm{H}_{2} 0,3 \mathrm{mg}$ $\mathrm{FeC1}_{3} \cdot 6 \mathrm{H}_{2} \mathrm{O}, 60 \mathrm{mg} \mathrm{KH} \mathrm{PO}_{4}, 50 \mathrm{mg} \mathrm{MgSO} \cdot 7 \mathrm{H}_{2} 0,30 \mathrm{~g}$ agar, $1 \mathrm{~L}$ distilled water, $\mathrm{pH}$ 6.5). A total of $10^{7}$ spores/ $\mathrm{mL}$ were cultured in PMMY medium [59] either in the absence or in the presence of $10 \mathrm{~g} / \mathrm{L}$ CPPs, and grown at $30^{\circ} \mathrm{C}$ and $250 \mathrm{rpm}$ in a rotary shaker (Model 481 Console incubator/refrigerated shaker, Thermo Scientific). Mycelia were harvested after $48 \mathrm{~h}$ of growth by centrifugation. Pellets were stored $\left(-80^{\circ} \mathrm{C}\right)$ to analyze the intracellular 
proteome, whereas supernatants were processed to study the extracellular proteome as follows: Supernatants were passed through a Nytal cloth filter and immediately centrifuged at $4{ }^{\circ} \mathrm{C}$ and $4500 \mathrm{rpm}$ for $5 \mathrm{~min}$ to remove any remaining mycelia. Then, they were refrigerated on ice and filtered through $0.45 \mu \mathrm{m}$ membrane filters (Millipore). An equal volume of pre-chilled $20 \%(\mathrm{w} / \mathrm{v})$ trichloroacetic acid in acetone containing $0.14 \%(\mathrm{w} / \mathrm{v})$ DTT was added to the filtered supernatants, mixed and incubated overnight at $-20^{\circ} \mathrm{C}$. Proteins were collected by centrifugation at $4500 \mathrm{rpm}$ for $5 \mathrm{~min}$ and $4^{\circ} \mathrm{C}$. The pellet was washed twice with pre-chilled acetone containing $0.07 \%$ $(\mathrm{w} / \mathrm{v})$ DTT and once with $80 \%(\mathrm{v} / \mathrm{v})$ acetone/Milli-Qwater.

Intracellular proteins were obtained following the protocol developed by Jami and co-workers [59]. After grinding the frozen mycelia to a fine powder in a pre-cooled mortar using liquid nitrogen, two grams of the final powder was resuspended (stirred at $4^{\circ} \mathrm{C}$ for $2 \mathrm{~h}$ ) in $10 \mathrm{ml}$ of $10 \mathrm{mM}$ potassium phosphate buffer $\left(\mathrm{K}_{2} \mathrm{HPO}_{4}: \mathrm{KH}_{2} \mathrm{PO}_{4} ; \mathrm{pH} 7.4\right)$ containing $0.07 \%(\mathrm{w} / \mathrm{v}) \mathrm{DTT}$ and supplemented with one tablet of the protease inhibitor mixture COMPLETE ${ }^{\mathrm{TM}}$ (Roche AppliedScience). The mixture was clarified twice by centrifugation at $13200 \mathrm{rpm}$ for $5 \mathrm{~min}$. Extracellular proteins were obtained from the same cultures following the protocol of Jami and co-workers [49]. After nytal filtration, supernatans were centrifuged twice (3900 rpm for 5 min and $13200 \mathrm{rpm}$ for $5 \mathrm{~min}$ ) at $4^{\circ} \mathrm{C}$ and filtered through $0.45 \mu \mathrm{m}$ filters. Intracellular and extracellular proteins were precipitated, washed and resuspended in sample buffer as described previously [49,59]. Samples were stored at $-80^{\circ} \mathrm{C}$. Protein concentration was estimated according to the Bradford method.

\section{2-DE gel electrophoresis and analysis of differential protein expression}

Bidimensional electrophoresis and protein determination were made as described by Jami and co-workers [59] by loading $450 \mu \mathrm{g}$ of soluble proteins in the sample buffer (see above) onto 18-cm IPG strips (GE Healthcare) with non linear (NL) pH 4-7 gradient (extracellular proteome) or NL pH 3-10 (cytoplasmic proteome). The second dimension SDS-PAGE was run in $12.5 \%$ polyacrylamide in an Ettan Dalt Six apparatus (GE Healthcare). Gels were dyed with Colloidal Coomassie (CC) [60], which provides high reproducibility.

2-DE gels were scanned using an ImageScanner II (GE Healthcare), digitalized with Labscan 5.00 (v1.0.8) software (GE Healthcare) and analyzed with the ImageMaster ${ }^{\mathrm{TM}} 2 \mathrm{D}$ Platinum v5.0 software (GE Healthcare). Three gels of each condition obtained from three independent cultures (biological replicates) were analyzed to guarantee representative results. After automated spot detection and manual revision, relative volumes were used to quantify and compare the gel spots. Proteins were considered to be differentially expressed when the ratio of the relative volume average (three gels) between strains was higher than 1.5 and the p-value was $<0.05$.

\section{Protein Identification by peptide mass fingerprint and tandem MS}

Protein spots of interest were manually excised from the Colloidal Commassie-stained gels, digested following the method of Havlis and co-workers [61] and processed for further analysis as indicated before [59]. Samples were analyzed with a 4800 Proteomics Analyzer MALDI-TOF/ TOF mass spectrometer (Applied Biosystems). The produced peptide mass fingerprints were collected and represented as a list of monoisotopic molecular weights using the 4000 Series Explorer v3.5.3 software (Applied Biosystems). Hence, from each MS spectra, the ten most intensive precursors were selected for MS/MS analyses with CID (atmospheric gas was used) in $2-\mathrm{kV}$ ion reflector mode and precursor mass windows of \pm 7 Da. For protein identification, Mascot Generic Files combining MS and MS/MS spectra were automatically created and used to interrogate a non-redundant protein database using a local license of Mascot v 2.2 from Matrix Science through the Protein Global Server (GPS) v 3.6 (Applied Biosystems). Search parameters for the peptide mass fingerprints and tandem MS spectra obtained were set as follows: (i) NCBInr (2009.11.03) sequence databases were used; (ii) taxonomy: All entries (9993394 sequences, 3409286210 residues); (iii) fixed and variable modifications were considered (Cys as S carbamidomethyl derivative and Met as oxidized methionine); (iv) one missed cleavage site was allowed; (v) precursor tolerance was $100 \mathrm{ppm}$ and MS/MS fragment tolerance was $0.3 \mathrm{Da}$; (vi) peptide charge: $1+$; and (vii) the algorithm was set to use trypsin as the enzyme. When the global Mascot score was greater than 83 with a significance level of $\mathrm{p}<0.05$ protein candidates were considered valid. Additional criteria for confident identification were that the protein match should have at least $15 \%$ sequence coverage; for lower coverage, only those proteins with a Mascot ions score above 54 and at least two peptides identified in the tandem MS analysis (with a significance level of $\mathrm{p}<0.05$ ), were considered valid.

\section{Additional material}

Additional file 1: Additional Figure 1. Milk clotting assay for casein, casamino acids, NZ Amino A or phosphoserine. A. Serial dilutions (1/ 2) of a pure preparation of chymosin (500 ng) and the corresponding concentration in $\mathrm{mg} / \mathrm{L}$. B. Effect of casein, casamino acids, NZ Amino A and phosphoserine on chymosin production by strains TG-87 and TAPL4. Culture supernatants from these strains were serially diluted from $1 / 2$ to $1 / 512$ (DF). No dilution is denoted as WD. The number of wells where milk clotting takes place (white precipitate) is proportional to the 
concentration of chymosin that is present in the culture supernatant. The chymosin concentration range that is present in those wells with clotting, has been estimated using the data obtained from panel A as it is indicated in the Methods section.

Additional file 2: Supplementary tables, Table S1. Intracellular proteins overrepresented in the absence of phosphopeptides. Fold change and $p$-value are indicated for those proteins present in both strains. Otherwise, non-available (N/A) is shown. Table S2. Intracellular proteins overrepresented in the presence of phosphopeptides. Fold change and $\mathrm{p}$-value are indicated for those proteins present in both strains. Otherwise, non-available (N/A) is shown. Table S3. Extracellular proteins overrepresented in the absence of phosphopeptides. Fold change and $p$-value are indicated for those proteins present in both strains. Otherwise, non-available (N/A) is shown. Table S4. Extracellular proteins overrepresented in the presence of phosphopeptides. Fold change and $p$-value are indicated for those proteins present in both strains. Otherwise, non-available (N/A) is shown.

\section{List of abbreviations}

Ble: Phleomycin; BSA: Bovine seroalbumin; CC: Colloidal Coomassie; Chy: Chymosin; CIA: chloroform-isoamyl alcohol; CPPs: Casein phosphopeptides; DTT: 1,4-dithio-D-threitol; ER: Endoplasmic reticulum; Gla: Glucoamylase; MALDI-TOF: Matrix-assisted laser desorption/ionization-Time of Flight

\section{Acknowledgements}

This work was supported by a grant of the European Union (EUROFUNGBASE LSSG-CT-2005-018964). K. Kosalková was supported by a Torres Quevedo contract (PTQ05-02-02553) of the Ministry of Science and Innovation of Spain (MICINN). M.G. Florez received a fellowship of the University of Pamplona (Colombia). We thank M. Shoda for providing the A oryzae amyB promoter (pTAex3).

\section{Author details}

'From INBIOTEC, Instituto de Biotecnología de León, Avda. Real n. 1, Parque Científico de León, 24006 León, Spain. ²From Área de Microbiología, Departamento de Biología Molecular, Universidad de León, Campus de Vegazana s/n; 24071 León, Spain.

\section{Authors' contributions}

KK performed main experiments, carried out the data analysis and wrote the initial part of the manuscript. CGE was involved in data analysis and interpretation, wrote the results of the proteomic studies and revised the manuscript. CB carried out in-gel digestions and mass-spectrometric analyses. MGF participated in plasmid construction and transformants selection. MSJ carried out the proteome sample preparation and the 2-DE analyses. MAP contributed to dephosphorylation experiments. JFM designed and conducted this research project, being also responsible for manuscript preparation, writing and revision. All authors read and approved the final manuscript.

\section{Competing interests}

The authors declare that they have no competing interests.

Received: 4 October 2011 Accepted: 10 January 2012 Published: 10 January 2012

\section{References}

1. Machida M, Asai K, Sano M, Tanaka T, Kumagai T, Terai G, Kusumoto K, Arima T, Akita O, Kashiwagi Y, Abe K, Gomi K, Horiuchi H, Kitamoto K, Kobayashi T, Takeuchi M, Denning DW, Galagan JE, Nierman WC, Yu J, Archer DB, Bennett JW, Bhatnagar D, Cleveland TE, Fedorova ND, Gotoh O, Horikawa H, Hosoyama A, Ichinomiya M, Igarashi R, et al: Genome sequencing and analysis of Aspergillus oryzae. Nature 2005, 438:1157-1161.

2. Pel HJ, de Winde JH, Archer DB, Dyer PS, Hofmann G, Schaap PJ, Turner G, de Vries RP, Albang R, Albermann K, Andersen MR, Bendtsen JD, Benen JAE, van den Berg M, Breestraat S, Caddick MX, Contreras R, Cornell M, Coutinho PM, Danchin EGJ, Debets AJM, Dekker P, van Dijck PWM, van
Dijk A, Dijkhuizen L, Driessen AJM, d'Enfert C, Geysens S, Goosen C, Groot GS, et al: Genome sequencing and analysis of the versatile cell factory Aspergillus niger. Nature 2007, 25:221-231.

3. Archer DB, Jeenes DJ, Mackenzie DA: Strategies for improving heterologous protein production from filamentous fungi. Antonie van Leeuwenhoek 1994, 65:245-250.

4. Gouka RJ, Punt PJ, van den Hondel CA: Efficient production of secreted proteins by Aspergillus: Progress, limitations and prospects. App/ Microbiol Biotechnol 1997, 47:1-11.

5. van den Hombergh JP, van de Vondervoort PJ, Fraissinet-Tachet L, Visser J: Aspergillus as a host heterologous protein production: the problem of proteases. Trends Biotechnol 1997, 15:256-263.

6. Conesa A, Punt PJ, van Luijk N, van den Hondel CA: The secretion pathway in filamentous fungi: a biotechnological view. Fungal Genet Biol 2001, 33:155-171.

7. Peberdy JF: Protein secretion in filamentous fungi-trying to understand a higly productive black box. Trend Biotechnol 1994, 12:50-57.

8. Moralejo FJ, Cardoza RE, Gutiérrez S, Martín JF: Thaumatin production in Aspergillus awamori by use of expression cassettes with strong fungal promoters and high gene dosage. Appl Environ Microbiol 1999, 65:1168-1174

9. van den Brink HJ, Petersen SG, Rahbek-Nielsen H, Hellmuth K, Harboe M: Increased production of chymosin by glycosylation. J Biotechnol 2006, 125:304-310.

10. Wösten HA, Moukha SM, Sietsma JH, Wessels JG: Localization of growth and secretion of proteins in Aspergillus niger. J Gen Microbiol 1991 137:2017-2023.

11. Fukuda K, Yamada K, Deoka K, Yamashita S, Ohta A, Horinouchi H: Class III chitin synthase ChsB of Aspergillus nidulans localizes at the sites of polarized cell wall synthesis and is required for conidial development. Eukaryot Cell 2009, 8:945-956.

12. Lombraña M, Moralejo FJ, Pinto R, Martín JF: Modulation of Aspergillus awamori thaumatin secretion by modification of bipA gene expression. Appl Environ Microbiol 2004, 70:5145-5152.

13. Archer DB, Peberdy JF: The molecular biology of secreted enzyme production by fungi. Crit Rev Biotechnol 1997, 17:273-306.

14. Ward PP, Lo J-Y, Duke M, May GS, Headon DR, Conneely OM: Production of biologically active recombinant human lactoferrin in Aspergillus oryzae. Nat Biotechnol 1992, 10:784-189.

15. Broekhuijsen MP, Mattern IE, Contreras R, Kinghorn JR, van den Hondel CAMJJ: Secretion of heterologous protein by Aspergillus niger: production of active human interleukin-hlL6 fusion protein. $J$ Biotechnol 1993, 31:135-145.

16. Cullen D, Gray GL, Wilson LJ, Hayenga KJ, Lamsa MH, Rey MW, Norton S, Berka RM: Controlled expression and secretion of bovine chymosin in Aspergillus nidulans. Bio/Technology 1987, 5:369-376.

17. Tsuchiya K, Gomi K, Kitamoto K, Kumagai C, Tamura G: Secretion of calf chymosin from the filamentous fungus Aspergillus oryzae. Appl Microbiol Biotechnol 1993, 40:327-332.

18. Cardoza RE, Gutiérrez S, Ortega N, Colina A, Casqueiro J, Martín JF: Expression of a synthetic copy of the bovine chymosin gene in Aspergillus awamori from constitutive and $\mathrm{pH}$-regulated promoters and secretion using two different pre-pro sequences. Biotechnol and Bioengineer 2003, 83:249-259.

19. Sirover MA: New insights into an old protein: the functional diversity of mammalian glyceraldehyde-3-phosphate dehydrogenase. Biochim Biophys Acta 1999, 1432:159-184.

20. Kawahara T, Otani H: Stimulatory effects of casein phosphopeptide (CPPIII) on mRNA expression of cytokines in Caco-2 cells. Biosci Biotechnol Biochem 2004, 68:1779-1781.

21. Kitts DD, Nakamura S: Calcium-enriched casein phosphopeptide stimulates release of IL- 6 cytokine in human epithelial intestinal cell line. J Dairy Res 2006, 73:44-48.

22. Kumagai $\mathrm{H}$, Sakai $\mathrm{H}$ : A porcine brain protein ( $35 \mathrm{~K}$ protein) which bundles microtubules and its porcine brain protein as glyceraldehyde 3phosphate dehydrogenase. J Biochem (Tokyo) 1993, 93:1259-1269.

23. Kawamoto R, Caswell A: Autophosphorylation of glyceraldehydephosphate dehydrogenase and phosphorylation of proteins from skeletal muscle microsomes. Biochemistry 1986, 25:657-661.

24. Hessler RJ, Blackwood RA, Brock TG, Francis JW, Harsh DM, Smolen JE: Identification of glyceraldehyde-3-phosphate dehydrogenase as a Ca2 
+-dependent fusogen in human neutrophil cytosol. J Leukocyte Biol 1998, 63:331-336.

25. Tisdale EJ: Glyceraldehyde-3-phosphate dehydrogenase is required for vesicular transport in the early secretory pathway. J Biol Chem 2001, 276:2480-2486.

26. Meganathan R: Ubiquinone biosynthesis in microorganisms. FEMS Microbiol Lett 2001, 203:131-139.

27. Munro S, Pelham HR: An Hsp70-like protein in the ER: identity with the $78 \mathrm{kd}$ glucose-regulated protein and immunoglobulin heavy chain binding protein. Cell 1986, 46:291-300.

28. Todd RB, Greenhalgh JR, Hynes MJ, Andrianopoulos A: TupA, the Penicillium marneffei Tup $1 \mathrm{p}$ homologue, represses both yeast and spore development. Mol Microbiol 2003, 48:85-94.

29. Andrianopoulos A, Kourambas S, Sharp JA, Davis MA, Hynes MJ: Characterization of the Aspergillus nidulans $n m r A$ gene involved in nitrogen metabolite repression. J Bacteriol 1998, 180:1973-1977.

30. Lamb HK, Ren J, Park A, Johnson C, Leslie K, Cocklin S, Thompson P, Mee C, Cooper A, Stammers DK, Hawkins AR: Modulation of the ligand binding properties of the transcription repressor NmrA by GATA-containing DNA and site-directed mutagenesis. Protein Sci 2004, 13:3127-3138.

31. Kudla B, Caddick MX, Langdon T, Martinez-Rossi NM, Bennett CF, Sibley S, Davies RW, Arst HN: The regulatory gene areA mediating nitrogen metabolite repression in Aspergillus nidulans. Mutations affecting specificity of gene activation alter a loop residue of a putative zinc finger. EMBO J 1990, 9:1355-1364.

32. Wilson RA, Arst HN: Mutational analysis of AreA, a transcriptional activator mediating nitrogen metabolite repression in Aspergillus nidulans and a member of the 'streetwise' GATA family of transcription factors. Microbiol Mol Biol Rev 1998, 62:586-596.

33. Coen ML, Lerner CG, Capobianco JO, Goldman RC: Synthesis of yeast cell wall glucan and evidence for glucan metabolism in a Saccharomyces cerevisiae whole cell system. Microbiology 1994, 140:2229-2237.

34. Pazzagli L, Pantera B, Carresi L, Zoppi C, Pertinhez TA, Spisni A, Tegli S, Scala A, Cappugi G: Cerato-platanin, the first member of a new fungal protein family: cloning, expression, and characterization. Cell Biochem Biophys 2006, 44:512-521.

35. Britton JR, Kastin AJ: Biologically active polypeptides in milk. Am J Med SCi 1991, 301:124-132

36. Schlimme $\mathrm{E}$, Meisel $\mathrm{H}$ : Bioactive peptides derived from milk proteins. Structural, physiological and analytical aspects. Nahrung 1995, 39:1-20

37. Lee YS, Noguchi T, Naito H: Intestinal absorption of calcium in rats given diets containing casein or amino acid mixture: the role of casein phosphopeptides. Br J Nutr 1983, 49:67-76.

38. Mikkänen HM, Wasserman RH: Enhanced absorption of calcium by casein phosphopeptides in rachitic and normal chicks. J Nutr 1980, 110:2141-2148.

39. Hata I, Higashiyama S, Otani H: Identification of a phosphopeptide in bovine as1-casein digest as a factor influencing proliferation and immunoglobulin production in lymphocyte cultures. J Dairy Res 1998, 65:569-578.

40. Hirayama M, Toyota K, Yamaguchi G, Hidaka H, Naito H: HPLC analysis of commercial casein phosphopeptides (CPP). Biosci Biotechnol Biochem 1992, 56:1126-1127.

41. Otani $H$, Watanabe $T$, Tashiro $Y$ : Effects of bovine $\beta$-casein (1-28) and its chemically synthesized partial fragments on proliferative responses and immunoglobulin production in mouse spleen cell cultures. BiosCi Biotechnol Biochem 2001, 65:2489-2495.

42. Moralejo FJ, Cardoza RE, Gutiérrez S, Sisniega H, Faus I, Martín JF: Overexpression and lack of degradation of thaumatin in an aspergillopepsin A-defective mutant of Aspergillus awamori containing an insertion in the pepA gene. Appl Microbiol Biotechnol 2000, 54:772-777.

43. Guilloteau P, Romé V, Delaby L, Mendy F, Roger L, Chayvialle JA: A new role of phosphopeptides as bioactive peptides released during milk casein digestion in the young mammal: regulation of gastric secretion. Peptides 2009, 30:2221-2227.

44. DeModena JA, Gutiérrez S, Velasco J, Fernández FJ, Fachini RA, Galazzo JL, Hughes DE, Martín JF: The production of cephalosporin C by Acremonium chrysogenum is improved by the intracellular expression of a bacterial hemoglobin. Biotechnology 1993, 11:926-929.

45. Hofmann G, Diano A, Nielsen J: Recombinant bacterial hemoglobin alters metabolism of Aspergillus niger. Metabol Engineer 2009, 1:8-12.
46. Suthar DH, Chattoo BB: Expression of Vitreoscilla hemoglobin enhances growth and levels of a-amylase in Schwanniomyces occidentalis. Appl Microbiol Biotechnol 2006, 72:94-102.

47. Jeffery CJ: "Moonlighting proteins". Trends Biochem Sci 1999, 24:8-11.

48. Gancedo C, Flores CL: Moonlighting proteins in yeasts. Microbiol Mol Biol Rev 2008, 72:197-210.

49. Jami MS, García-Estrada C, Barreiro C, Abel-Alberto C, Salehi-Najafabadi Z, Martín JF: The Penicillium chrysogenum extracellular proteome. Conversion from a food-rotting strain to a versatile cell factory for white biotechnology. Mol Cell Proteomics 2010, 9:2729-2744.

50. Collinge AJ, Trinci APJ: Hyphal tips of wild-type and spreading colonial mutants of Neurospora crassa. Arch Microbiol 1974, 99:353-368.

51. Silverman-Gavrila LB, Lew RR: Calcium gradient dependence of Neurospora crassa hyphal growth. Microbiology 2001, 149:2475-2485.

52. Silverman-Gavrila LB, Lew RR: Regulation of the tip-high $\left[\mathrm{Ca}^{2+}\right]$ gradient in growing hyphae of the fungus Neurospora crassa. Eur J Cell Biol 2003, 80:379-390.

53. Gutiérrez S, Velasco J, Marcos AT, Fernández FJ, Fierro F, Barredo JL, Díez B, Martín JF: Expression of the cefG gene is limiting for cephalosporin biosynthesis in Acremonium chrysogenum. Appl Microbiol Biotechnol 1997, 48:606-614.

54. Sugano Y, Nakano R, Sasaki K, Shoda M: Efficient heterologous expression in Aspergillus oryzae of a unique dye-decolorizing peroxidase DyP, of Geotrichum candidum. Appl Environ Microbiol 2000, 66:1754-1758.

55. Faus I, Patiño C, Río JL, del Moral C, Barroso HS, Rubio V: Expression of a synthetic gene encoding the sweet-tasting protein thaumatin in Escherichia coli. Biochem Biophys Res Commun 1996, 229:121-127.

56. Chomczynski P, Sacchi N: Single-step method of RNA isolation by acid guaidinium thiocyanate-phenol-chloroform extraction. Anal Biochem 1987, 162:156-159

57. Sambrook J, Russell DW: Molecular Cloning: A Laboratory Manual Cold Spring Harbor Laboratory: Cold Spring Harbor, NY; 2001.

58. Eymann C, Becher D, Bernhardt J, Gronau K, Klutzny A, Hecker M: Dynamics of protein phosphorylation on Ser/Thr/Tyr in Bacillus subtilis. Proteomics 2007, 7:3509-3526.

59. Jami MS, Barreiro C, García-Estrada C, Martín JF: Proteome analysis of the penicillin producer Penicillium chrysogenum: Characterization of protein changes during the industrial strain improvement. Mol Cell Proteomics 2010, 9:1182-1198.

60. Candiano G, Bruschi M, Musante L, Santucci L, Ghiggeri GM, Carnemolla B, Orecchia P, Zardi L, Righetti PG: Blue silver: a very sensitive colloidal Coomassie G-250 staining for proteome analysis. Electrophoresis 2004, $25: 1327-1333$

61. Havlis J, Thomas H, Sebela M, Shevchenko A: Fast-response proteomics by accelerated in-gel digestion of proteins. Anal Chem 2003, 75:1300-1306.

doi:10.1186/1475-2859-11-5

Cite this article as: Kosalková et al:: Casein phosphopeptides drastically increase the secretion of extracellular proteins in Aspergillus awamori. Proteomics studies reveal changes in the secretory pathway. Microbial Cell Factories 2012 11:5.

\section{Submit your next manuscript to BioMed Central and take full advantage of:}

- Convenient online submission

- Thorough peer review

- No space constraints or color figure charges

- Immediate publication on acceptance

- Inclusion in PubMed, CAS, Scopus and Google Scholar

- Research which is freely available for redistribution 